\title{
Case Study Of A Small Scale Polytechnic Entrepreneurship Capstone Course Sequence
}

Rustin D. Webster, Purdue University, USA

Richard Kopp, Purdue University, USA

\begin{abstract}
A multidisciplinary entrepreneurial senior capstone has been created for engineering technology students at a research I land-grant university statewide extension. The two semester course sequence welcomes students from Mechanical Engineering Technology, Electrical Engineering Technology, Computer Graphics Technology, and Organizational Leadership. The goal was to provide an avenue for technology students to learn about, actively participate in, and form small scale startups in a multidisciplinary approach. Student are introduced to fundamental techniques and methodologies for effective product development, such as design thinking, technical data package, rapid prototyping, testing, and validation. As well as entrepreneurship concepts, such as product ideation, market research, capital exploration, customer acquisition, customer discovery, intellectual protection, marketing and branding, and leadership. The capstone has provided real-world, hands-on learning of the components and processes necessary to take a product idea from initial concept to successful business. Currently entering in to its third year, the capstone continues to evolve. This paper presents a brief description of the capstone, including formation, execution, and outcomes. The curriculums used are outlined and future changes are discussed. Lastly, the presentation of challenges, lessons learned, and course accomplishments will be discussed.
\end{abstract}

Keywords: Capstone; Entrepreneurship; Polytechnic; Engineering Technology

\section{INTRODUCTION}

$\mathscr{T}$ he majority of universities have missed three revolutions since WWII: quality, information technology, and the entrepreneurial revolution (Goldberg \& Somerville, 2014). Goldberg and Somerville (2014) used the word "missed" in the sense that private enterprise has been shaped by the creative and innovative spirts of so many entrepreneurs, such as Sam Walton, Steve Jobs, Bill Gates, and Elon Musk, all the while universities have relatively remained untouched and unchanged. Recently, there has been a movement by universities to develop and offer additional and new lectures, courses, capstones, certificates, and even degrees centered on innovation and entrepreneurship. In large part this is being contributed to industry voicing their concerns of the career readiness of college graduates, specifically graduates coming from Science, Technology, Engineering, and Mathematics (STEM) fields (Hard Research Associates, 2013). "Career readiness is the attainment and demonstration of requisite competencies that broadly prepare college graduate for a successful transition into the workplace" (The National Association of Colleges and Employers, 2016, p. 1). Employers' priorities of old and new workers are changing. For example, often it is now of higher importance that an employee can contribute to the innovation and creativity in the workplace rather than be an obedient worker who can and does only one job well (Hart Research Associates, 2013; Wagner, 2012). A 2013 study by Hart Research Associates (2013) found that over $90 \%$ of the respondents believe that a students' ability to think critically, communicate clearly, and solve complex problems in more important than even the student's specific undergraduate major. Innovation, creativity and entrepreneurial principles need to become a priority for engineering students who want to be successful as workers and citizens in the $21^{\text {st }}$ century.

Universities are traditionally known for producing engineers with expertise in their chosen discipline. Individuals with a depth of expertise, knowledge, and understanding. However, the majority are lacking the cross-discipline 
competencies and the breadth of skills, such as communication, critical thinking, teamwork, etc. that are often needed in a global, digital, and information economy (Levine \& Dean, 2012). The National Association of Colleges and Employers (2016) lists seven competencies needed by students: critical thinking/problem solving, oral/written communications, teamwork/collaboration, information technology application, leadership, professionalism/work ethic, and career management. The majority of engineering programs, specifically at tier 1 research institutions are not graduating engineers who meet these broad-based competencies. This often results in graduates who are Ishaped students with deep disciplinary knowledge but have little or no ability to cross boundaries between disciplines. An alternative is to encourage the development of T-shaped professionals (see Figure 1). The horizontal element is a simple addition but can be highly impactful to the $21^{\text {st }}$ century engineering student. It allows them to have depth and breadth in their skills, knowledge, and competencies.

Figure 1. T-shaped Professional

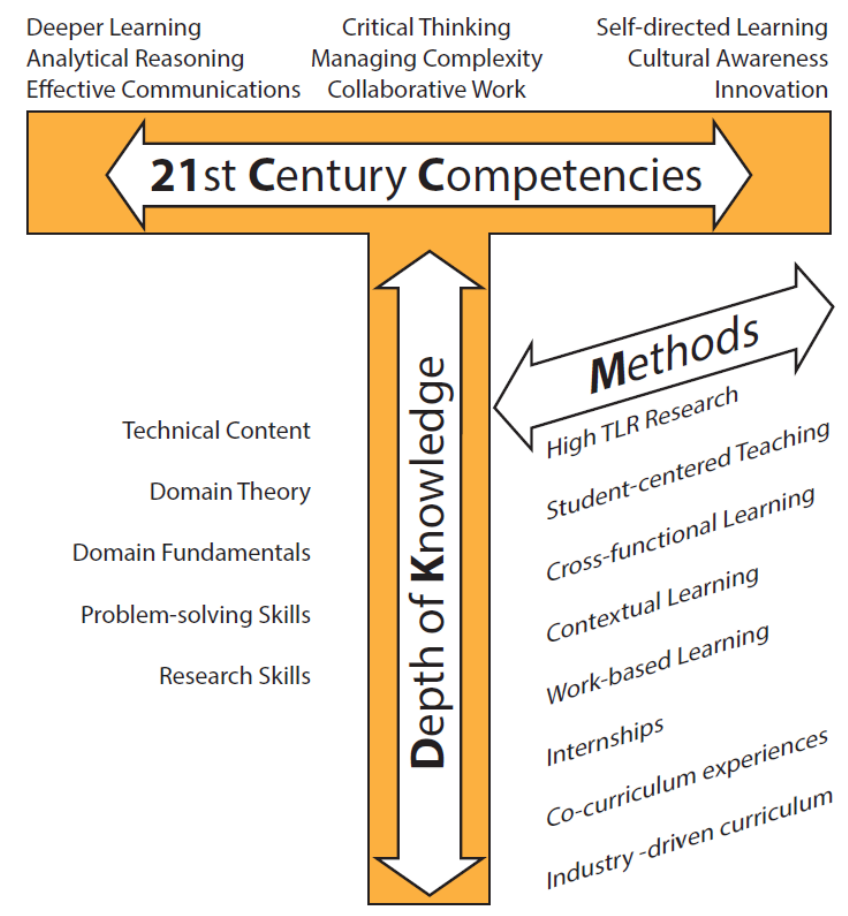

Entrepreneurship education in general and specifically entrepreneurial capstone courses can help solve the above mentioned employers' problems. It naturally incorporates the horizontal elements of the T-shaped professional. The multidisciplinary entrepreneurial senior capstone, which is presented in this paper, provided an opportunity for engineering technology students to cross many disciplines while developing $21^{\text {st }}$ century competencies, such as team work, communication, critical thinking, project management, etc. It moved beyond writing business plans and reading about starting a company and actually launched startups.

\section{CASE STUDY}

"Entrepreneurship education is not as simple as listening to entrepreneurs speak about successes and failures. Entrepreneurship education is not just about the "how" of business and commercialization. Entrepreneurship is an active process that demands thoughtful, active learning" (Huang-Saad, Gibson, Goebel, Sheridan \& McNaughton, 2015 , p. 1). In other words, the students must learn by doing. This concept is deeply integrated into the Purdue Polytechnic Institute's vision and mission statements (Purdeu Polytechnic Institute, 2015b). It is also a primary element of the college's transformation efforts, which started in 2013 and continue today. Extraordinary opportunities are being offered to students and faculty which touch all parts of the college, including curricula, 
teaching methods and learning spaces. The breadth and depth of the transformation are enormous and are aimed at the following:

- $\quad$ "Producing more graduates who are not only more capable of meeting the evolving needs of industries and communities, but who have a thirst for life-long learning and recognize the opportunities and challenges that technology brings society" (Purdeu Polytechnic Institute, 2015b, p. 4).

- "Creating a learning environment that is more student-centered with ground-breaking teaching/learning techniques, includes competency-based and other innovative learning approaches giving students greater flexibility and autonomy in pursuing their personal interests, and fosters academic success across a broader and more diverse population" (Purdeu Polytechnic Institute, 2015b, p. 4).

- "Expanding the college's state and global engagement and its research that are not only inspired by and more closely tied to the needs of industry and communities, but that also infuses innovation and entrepreneurship and integrates those skills into the college's learning environment" (Purdeu Polytechnic Institute, 2015b, p. 4).

Starting in the summer of 2014, faculty and administrators at Purdue Polytechnic Institute and local community partners in the Louisville, KY metro area began to formulate a plan to introduce a yearlong multidisciplinary entrepreneurial-based capstone for the Purdue Polytechnic New Albany campus. The idea was accepted by faculty, staff, students, and administration when presented because it aligned with the transformation efforts underway. It also filled a gap in the existing University's entrepreneurial curriculum which focuses mainly on learning by reading, execution of business plans, and management of large firms. It was also the colleges first capstone course offering centered around entrepreneurship and at its core was the idea of learn by doing.

The capstone was approved by the college and received external funding to be offered for three years at a statewide extension location. After which it will go through a thorough evaluation. Expectations are that after year three the capstone will be rolled out to the other statewide locations (Purdeu Polytechnic Institute, 2015a, 2015b). Currently, entering its third year the capstone has evolved each year (see Table 1).

Table 1. Course summary by year

\begin{tabular}{|c|c|c|c|}
\hline \\
\hline & Year 1 & Year 2 & Year 3 \\
\hline Length (semesters) & Fall & Fall/Spring & Fall /Spring \\
\hline Instructor Structure & Team/Collaborative teaching ${ }^{1}$ & Co-teaching ${ }^{1}$ & Single instructor \\
\hline Teaming Structure & $\begin{array}{l}\text { Teams assigned or individual } \\
\text { projects }\end{array}$ & $\begin{array}{l}\text { Individual projects or teams } \\
\text { chosen by students }\end{array}$ & \multirow{6}{*}{ IN PLANNING } \\
\hline Project Scope & $\begin{array}{l}\text { Required to enter course with } \\
\text { product idea }\end{array}$ & $\begin{array}{l}\text { Course began with ideation and } \\
\text { creativity sessions }\end{array}$ & \\
\hline Opportunity Identification & $\begin{array}{l}\text { Requirements based on } \\
\text { students' desires }\end{array}$ & Lean Startup methodologies & \\
\hline Customer Discovery & $\begin{array}{l}\text { Student/teacher assumption } \\
\text { driven }\end{array}$ & Lean Startup methodologies ${ }^{2}$ & \\
\hline Product Development & Single prototype & Iterative prototyping & \\
\hline Funding & Internal & $\begin{array}{l}\text { Internal/Commercialization } \\
\text { Research Grants }\end{array}$ & \\
\hline
\end{tabular}

Notes: ${ }^{1}$ Two instructors total, ${ }^{2}$ Required weekly customer interviews

\section{Lab Facilities Overview}

Each year students were pushed to begin prototyping early and to reach their minimal viable product (MVP) as early as possible. In hopes that more in-depth customer discovery could take place. In order for this to take place the necessary resources (i.e. funding, material, and manufacturing equipment) had to be in place prior to starting the class. Specifically concerning the prototyping equipment, on site there are five open access working labs (one 
mechanical, one computer graphics, and three electrical based) for students, which all contain state of the art technology.

The advanced manufacturing lab contains common subtractive manufacturing equipment, such as saws and drills. However, it also contains two large professional level computer numerical control (CNC) machines: a lathe and 5axis mill. Over the last decade, rapid prototyping has begun to utilize additive manufacturing techniques more often. So the lab has been equipped with five fused deposition modeling (FDM) three-dimensional (3D) printers and one lamination-type 3D printer. The manufacturing lab contains two different laser cutting, etching, and engraving machines. Finally, metal work can be performed with typical bending and cutting hand tools, welding equipment, and a plasma/router CNC. The available equipment can be grouped by: metal, $\mathrm{CNC}$, wood, and 3D printing.

The computer graphics lab is titled the STEAM Design Center and consists of a gallery, two design studios, and a production studio. Features and services available within are: 3D modeling, animation, web programming, video production, large format printing, and audio recording. Studio A also includes a 20 foot long green screen. Finally, there is an analog and digital electronics, advanced RF communication, and electric power and controls lab. All labs are open to students from any department/degree and are stocked with common supplies and equipment.

\section{Year One}

The first time offering of the multidisciplinary entrepreneurial senior capstone was one semester long and was made available to students in Mechanical Engineering Technology (MET), Electrical Engineering Technology (EET), Computer Graphics Technology (CGT), and Organizational Leadership (OL) at the New Albany campus. The capstone was originally planned to be a two semester long sequence but due to mid-academic year approval and funding it was limited for year one. Initial design goal was to create an alternative to the technology-track approach for students, who possess a higher level of creativity and broader, more diverse interests. There were four students from MET and two from EET, one was a female. Course preparation and delivery was done by two faculty members, one each from MET and OL. There was also significant input from the director of research and innovation for Purdue Polytechnic Statewide, who was also instrumental in acquiring approval and funding for the capstone, along with mentoring the instructors and students. Both instructors had none or little personal startup experience but did have prior intrapreneural experience. The instructor structure is labeled as team/collaborative because classroom material was delivered by a sole instructor once the semester began.

\section{First Semester Curriculum}

The learning objectives were the following:

1. Identify techniques and methodologies to efficiently create a startup business based on engineered products and concepts

2. Implement the design process through proper use of prototyping, optimization, and customer feedback

3. Apply experiential learning to the process of discovery and hypothesis testing of new products and business models

4. Effectively document appropriate product and process information for customer \& investor review and presentations

5. Properly identify the real need in a design and the constraints imposed by the life cycle of the design

6. Utilize proven criteria for generating customer interest and development

7. Develop a summary business plan, and how to use it to test their business startup

8. Demonstrate what a "startup" is, and the activities that must be undertaken to launch both the company and the product into the market

The required texts were The Startup Owner's Manual (Blank \& Dorf, 2012) and Business Model Generation (Osterwalder \& Pigneur, 2010). The instructors also utilized The Lean LaunchPad Evidence-Based Entrepreneurship Educators Guide (Blank, Engel \& Hornthal, 2015) for course design and preparation. A large portion of the curriculum involved material from Steve Blank's website (www.steveblank.com) and the free online Udacity course titled: How to Build a Startup: The Lean LaunchPad (Blank \& Mullaney), which is divided into eight lessons. The 
Udacity course is an introduction to the customer development process created by Steve Blank to build startups, commonly technology-based. It encourages students to get out of the building and search for customer pains and needs. Once found the entrepreneur can develop a proper solution and establish a suitable business model by collecting massive amounts of customer and marketplace feedback in a process called customer discovery. "The emphasis of searching for a business model versus execution of a plan is at the heart of the Lean LaunchPad curriculum" Blank et al., 2015, p. 7).

Blank et al. (2015) lists three key principles of the Lean Startup method, which are:

1. Untested hypotheses (i.e. good guesses) are summarized in a Business Model Canvas (BMC) instead of creating an intricate business plan. This saves times and produces a diagram which shows how a company will create value for itself and its customers.

2. Customer development uses a "get out of the building" approach to test hypotheses. Emphasis is placed on nimbleness and speed in hopes of reaching a MVP (product containing only the critical features gathered from customer feedback). "Students go out and ask potential users, purchasers, and partners for feedback on all elements of the business model, including product features, pricing, distribution channels, and affordable customer acquisition strategies" (p.7). Feedback is then used to revise assumptions and make small adjustments (i.e. iterations) or larger ones (i.e. pivots).

3. Agile development, which originated from the software industry but is a design/manufacturing methodology where prototypes are interactively and incrementally created.

The class met twice a week, and followed a flipped classroom design. Before each class students were assigned readings and Udacity videos to watch. Class time was then used for reviewing concepts, updating the BMC, exploring additional material, open discussions, prototyping, etc. Students were required to bring a startup/product idea to the first class. The classroom setting was of traditional fashion, where there were rows of tables/chairs and the instructor was stationed primarily in front of the classroom. Students presented their work (i.e. BMC and initial prototype) the final week of the 15 week semester to faculty, staff, and community members.

\section{Year Two}

The second offering of the capstone was two semesters long and was made available to the same student population as year one. Five students from MET enrolled the first semester, all were male. The second semester returned three of the original students while adding a forth, who joined an existing team due to his outside efforts on the project during the first semester. Fortunately, each project which started in the first semester retained a student representative during semester two. Course preparation and delivery was done by two different faculty members, one each from MET and CGT. Once again there was significant input from the director of research and innovation for Purdue Polytechnic Statewide. Both instructors had none or little personal startup experience but did have prior intrapreneural experience. The instructor structure is labeled as co-teaching because both teachers shared equal responsibility in planning, instruction, and assessment, and both were always present in class (Villa, Thousand \& Nevin, 2013). "Some people say that co-teaching is a creative way to connect with and support others to help all children learn. Others say that co-teaching is a way to make schools more effective" (Villa et al., 2013, p. 5). No matter the instructors believed that the diversity co-teaching brought would be advantageous to the students.

\section{First Semester Curriculum}

The learning objectives were the following:

1. Communicate on Lean Startup methodology

2. Identify techniques and methodologies to efficiently create a startup business based on engineered products and concepts

3. Implement the design process through proper use of prototyping, optimization, and customer feedback

4. Apply experiential learning to the process of discovery and hypothesis testing of new products and business models 
5. Effectively document appropriate product and process information for customer \& investor review and presentations

6. Properly identify the real need in a design and the constraints imposed by the life cycle of the design

7. Utilize proven criteria for generating customer interest and development

The required text was the Business Model Generation (Osterwalder \& Pigneur, 2010). The instructors once again utilized The Lean LaunchPad Evidence-Based Entrepreneurship Educators Guide (Blank et al., 2015), Steve Blank's website (www.steveblank.com), and the free online Udacity course titled: How to Build a Startup: The Lean LaunchPad (Blank \& Mullaney, n.d).

The class met twice a week, and followed the flipped classroom design only during the Udacity portion. The classroom setting was of untraditional fashion. The instructors utilized a small active learning room which consisted of a round table, white boards, and multimedia equipment. The instructors shared the same table space as the students and never gave standing lectures.

The instructors believed that one Udacity lessons could be covered per week, which would allow for additional material to be included. The 15 week schedule was subdivided as:

- Weeks 1-3: Ideation/Creativity Sessions and Commercialization \& Research Grants (CRG)

- Weeks 4-11: Udacity Lessons (8 total)

- Weeks 12-15: Marketing, Branding, and Pitching

The course began with ideation sessions using techniques, such as brainstorming, worst idea, and daily user experience cataloging. The end goal was to have a list of potential and feasible product/project ideas that the students could individually or as a team pursue over the academic year. If students entered the course with an existing product/project idea it was vetted for feasibility by the class before the student was approved to proceed. Additionally, students were required to apply for startup funding by submitting a CRG proposal.

The primary purpose of the CRG is to enrich the quality of research, commercialization, and service learning experiences of university students by involving students in a funded collaboration with a faculty mentor. The student is expected to be the principal actor in the project and is responsible for the design, budgeting, and execution of the project, as well as identification of an appropriate faculty mentor from the college. The faculty mentor will provide subject matter expertise and appropriate project guidance. Both instructors believed that not only could extra funding improve the success rate but it was important for the students to learn how to write a professional grant proposal.

After the first three weeks, they began developing their products due to and presenting their findings from weekly customer discovery interviews (minimal five per week). The students were heavily critiqued each time on their presentation materials and communication skills (verbal and written) by the instructors and fellow students. The last four weeks of the course covered marketing and branding topics, such as logo design, color schemes, tag lines, web site hosting, website content, and website service providers. The last week also included a pitch presentation to faculty, staff, and community members, which included low-fidelity prototypes displays. When necessary the instructors solicited guest speakers related to the week's topic.

\section{Second Semester Curriculum}

The learning objectives were the following:

1. Utilize common techniques and methodologies to efficiently create a startup business based on engineered products and concepts

2. Effectively document appropriate product and process information for customer \& investor reviews and presentations.

3. Research opportunities and acquire revenue

4. Develop marketing, promotion, and branding material and outlets 
There was no required text or online learning course. The class met twice a week and in the same setting as the first semester. Each product had went through many design cycles due to the Lean Startup efforts in the first semester and had reached what was characterized as a low-fidelity prototype. Encouraged by the effort shown in the first semester, the instructors' focused on reaching a high-fidelity prototype and covering additional material believed to be needed for a successfully startup launch by the end of the second semester.

The first week were spent on reviewing, planning, and submissions for additional CRG funds. The second and third weeks covered intellectual property (IP) and technical data packages (TDP). Both instructors lacked the knowledge needed to cover IP protection. So a local professional was contacted and arrangements were made for a guest instructor. The next twelve weeks include various topics, such as website design and development, private placement (i.e. a funding round of securities which are sold not through a public offering, but rather through a private offering), crowdfunding, and IP workshops. Once again a local professional was arranged to cover the private placement material. At all times prototype development and brand development was also being conducted, most often outside of classroom time.

\section{Year Three and Beyond}

Year three is still being planned, however there has been some proposed changes for the future. Mainly, the vast amount of topics required to cover for a successful startup launch has introduced the need for two additional courses before the capstone year. A four course sequence therefore will allow the capstone semesters to focus more heavily on product development and increase the likelihood of launching the business in the second semester.

The New Albany campus only has engineering majors. However, its regional host, Indiana University Southeast has a business department but no engineering. Talks have taken place to form a collaboration between both institutions. The two additional courses identified are Contemporary Entrepreneurship (sophomore level) and New Venture Creation (junior level). The first course focuses on the entrepreneur personality, the entrepreneur skill set, and the entrepreneur ventures. The second emphasizes developing effective entrepreneurial skills and behaviours and includes the preparation of a feasibility study and comprehensive business model canvas. The proposed four course sequence should strengthen the skills sets that will lead to a higher success rate in launching a new business. A possible certificate awarded from the host institution in Innovation \& Entrepreneurship is also being discussed. If approved it would be unique to earn a degree from one institution and be awarded a certificate from another.

\section{EVALUATION}

When establishing the multidisciplinary entrepreneurial senior capstone, many of the same challenges present by other institutions were also encountered:

1. Approval from administration for funding, teaching time, resource utilization, etc. (Katona, York \& Slivovsky, 2106)

2. Marketing and recruiting students, especially from various majors, for the new course offering (Katona et al., 2016)

3. Creating a course that students from multiple majors can enroll in, get credit for, does not cause conflict with schedules, and is located in an available space, preferably an active learning space, on campus (Katona et al., 2016)

4. Recruiting instructors with the required skills and expertize (Katona et al., 2016)

After year two, administration and faculty believe that the entrepreneurial capstone experiment has been beneficial. Beneficial to the students due to the knowledge transferred to the enrolled students, some who continue to operate their startups, and to the campus from the positive publicity the course has gained in the community (Lincoln, 2015; Suddeath, 2015). 


\section{Lessons Learned}

More than half way through the journey the four instructors along with administration have learned many lessons. "These lessons are important to document both for this teaching team as we continue to revise and improve this course, and also for others in the community considering launching such a course" (Katona et al., 2016, p. 9).

\section{Customer Discovery}

First, the Lean Startup methodology can be effective in launching startups in a relatively short period of time. However, students must be pushed very hard by the instructors to conduct enormous amounts of customer interviews during discovery. Students often struggled and were uncomfortable with locating, arranging, and conducting the interviews. Instructors must also beware of students interviewing solely family, friends, and coworkers. They must be pushed to get out of their comfort zones and find interviewees in the appropriate settings, preferably where there product will be used or sold. Similarly, it often took many rounds of interviews before the students could effectively communicate their product (e.g. purpose, advantages, use case, etc.) to the customers.

Non-linear Design

Both the instructors and the students struggled with managing such unstructured projects. During semester one the projects were very nebulous, especially during customer discovery where design features and options often changed weekly. The instructors had to build time into the schedule/syllabus for unexpected issues and delays.

\section{Intrinsic Motivation}

"The students must have a personal connection and passion for their entrepreneurial endeavor" (Huang-Saad et al., 2015 , p. 8). This also includes team members if projects are team-based. When recruiting students, they must be made aware of the time commitment and course activities. Offering a more traditional engineering capstone course at the same time can help keep the head count low and encourages the right type of student to enroll. The most successful students from year one and two entered the course with a strong desire to start a company around an existing product idea.

\section{Hard vs Soft Products}

The instructors in year two allowed soft (i.e. software) and hard (i.e. manufactured goods) project ideas. They quickly learned that development paths and resources needed are quite different. It would be highly suggested that the course be limited to projects that meet the instructors' skills, knowledge, and strengths.

\section{Accomplishments}

Year one had four projects of which two were individual-based and two were two person teams. All projects consisted of hard products. At the end of the semester two of the teams had produced low fidelity prototypes while the other two projects were only able to complete initial market research, begin customer discovery, and complete early iterations of their BMC. Each team was expected to follow the Lean Startup methodology but from instructor interviews the principles and techniques, such as requiring 5-10 customer discovery interviews a week, were not strongly enforced. See Table 1 for comparisons between year one and two.

In year one, the most successful project was an automatic guitar tuner that will key each string with a simple pluck. It should be noted that the student entered the class already with a proof of concept prototype. Thus, the student used the course to further refine the offering and explore potential markets, and develop a business model.

Year two had three projects and finished with two successful startups. One project was a software offering and two were manufactured goods. All three projects originated in the first semester and were developed throughout both semesters. At completion two businesses were launched. E-compass (see), which is a cloud-based enterprise tool for manufacturers to reduce the amount of work it takes to stay environmentally compliant, and Codger Hill Outdoors 
(see Figure 3), which is an online sporting goods store which offers a wide range of products. Got1Holder (see Figure 4 and Figure 6) and EVN-Heat (see Figure 5 and Figure 7) are the first two offerings and are a result of the capstone.

In year two, both companies were able to conceptualize and develop their product(s) past the MVP stage, create company branding, websites (marketing, e-commerce, and database types), and marketing material, begin the IP protection process, conduct numerous public pitches, and begin small batch manufacturing based on industry ready TDPs.

Figure 2. E-compass Logo

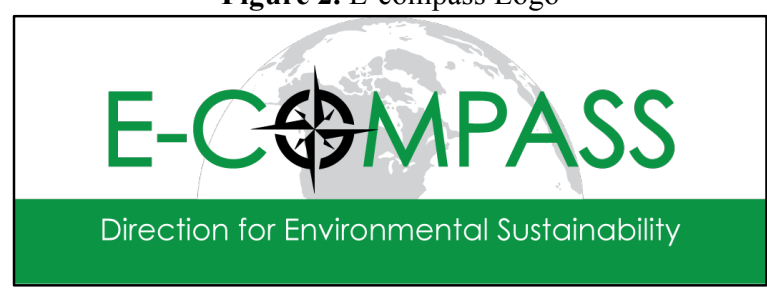

Figure 4. Got1Holder Logo

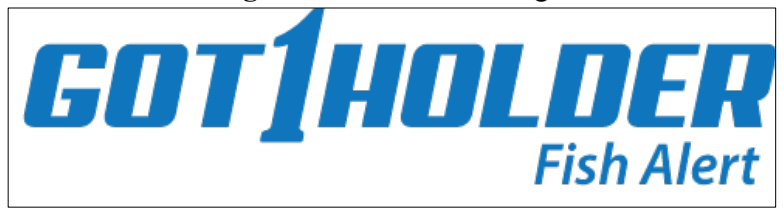

Figure 6. Got1Holder Prototype

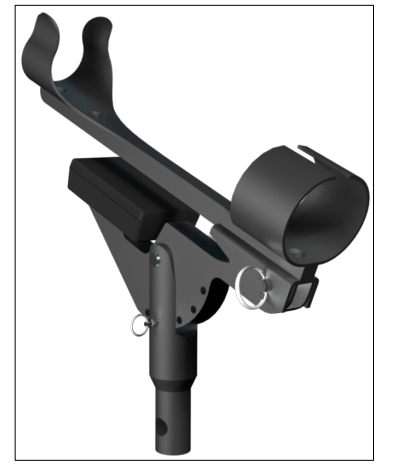

Figure 3. Codger Hill Outdoors Logo

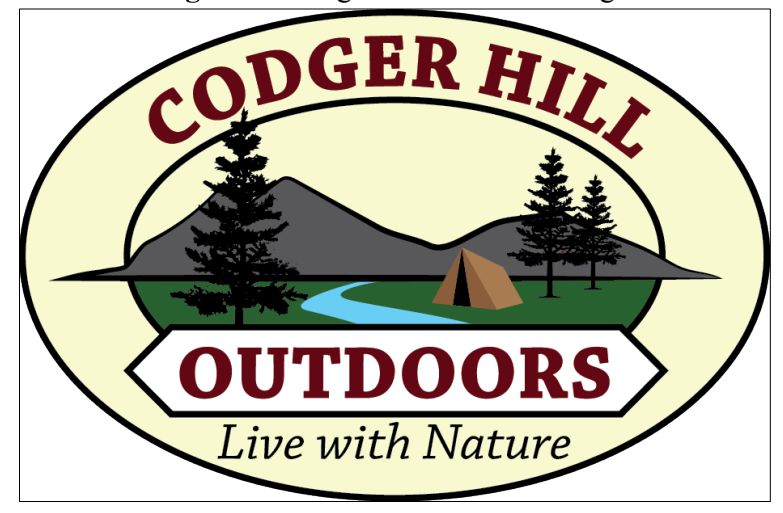

Figure 5. EVN-Heat Logo

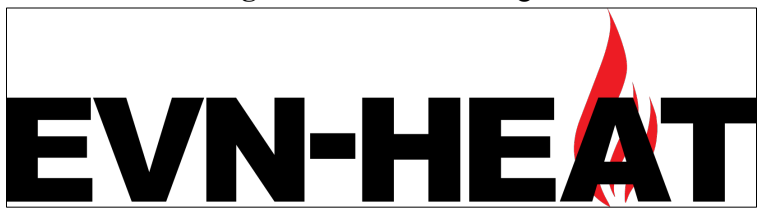

Figure 7. EVN-Heat Prototype

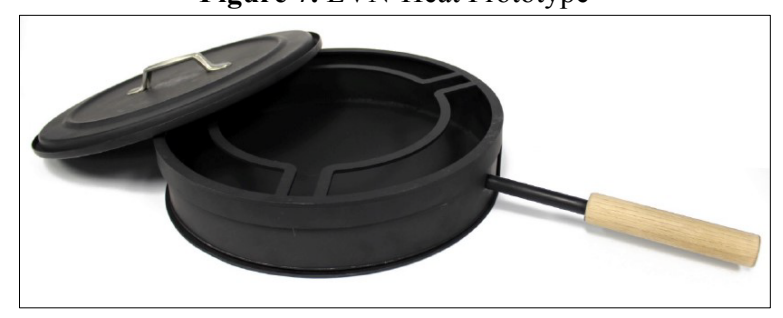

\section{CONCLUSION}

In conclusion, a multidisciplinary entrepreneurial senior capstone has been created for engineering technology students at a research I land-grant university statewide extension. The two semester course sequence welcomes students from all majors and provides an avenue for engineering technology students to learn about, actively participate in, and form small scale startups in a multidisciplinary approach. The paper discusses the formation, execution, and outcomes in hopes that it provides a reference point for other institutions. Much can be learned from 
our entrepreneurial capstone and others alike. As the demand for a whole new type of $21^{\text {st }}$ century engineer increases a capstone, such as described above, may be prove to be an effective solution.

\section{ACKNOWLEDGMENTS}

This work was made possible by a Purdue Polytechnic Institute Commercialization \& Research Grant faculty grant.

\section{AUTHOR BIOGRAPHIES}

Dr. Rustin Webster is an assistant professor at Purdue University. He teaches within the Purdue Polytechnic Institute and the School of Engineering Technology. He specializes in mechanical engineering and computer graphics technology. Dr. Webster previously worked for an aerospace engineering and analysis firm as an engineer, project manager, and researcher. His specialization was in mechanical design, research and development, and business development. He studied at Murray State University and the University of Alabama at Birmingham where his research was on immersive virtual learning environments for educational training purposes.

Richard D. Kopp is an Associate Professor at Purdue University. He teaches computer graphics courses within the Purdue Polytechnic Institute for the Department of Computer Graphics Technology. His current teaching interests are in digital illustration, video editing, and digital painting. Recently, Professor Kopp crossed over into mechanical engineering technology to co-teach an entrepreneurship capstone. Prior to joining the faculty in 1994, Richard worked as a publishing manager, assistant art director, and computer graphics artist. He earned a B.A. in Fine Arts from Indiana University Southeast and a M.F.A. from the University of Delaware.

\section{REFERENCES}

Blank, S., \& Dorf, B. (2012). The startup owner's manual: The step-by-step guide for building a great company (1st ed.). Pescadero, CA: K\&S Ranch, Inc.

Blank, S., Engel, J., \& Hornthal, J. (2015). Lean launchpad evidence-based entrepreurship educators guide. Retrieved from: https://venturewell.org/wp-content/uploads/Educators-Guide-Nov-2015-Final.pdf

Blank, S., \& Mullaney, K. (n.d). How to build a startup: The lean launchpad. Retrieved from: https://www.udacity.com/course/how-to-build-a-startup--ep245

Goldberg, D. E., \& Somerville, M. (2014). A whole new engineer. Douglas, MI: ThreeJoy Associates, Inc.

Hart Research Associates (2013). It takes more than a major: Employer priorities for college learning and student success. Washington, DC: Association of American Colleges \& Universities. Retrieved from: www.aacu.org/leap/public_opinion_research.cfm

Huang-Saad, A., Gibson, M., Goebel, J., Sheridan, R., \& McNaughton, B. (2015). Student learning outcomes from a multidisciplinary capstone entrepreneurship course. In Proceedings of Open, 2015. Washington, D.C.: VentureWell.

Katona, T. M., York, J. L., \& Slivovsky, L. (2016). Launching an interdisciplinary entrepreneurial capstone design experience. In Proceedings of Open, 2016. Portland, Oregon: VentureWell.

Levine, A., \& Dean, D. R. (2012). Generation on a tightrope (3rd ed.). San Francisco, CA: Jossey-Bass.

Lincoln, S. (2015). New albany pilot program brings entrepreneur experience to students. Retrieved from: https://polytechnic.purdue.edu/newsroom/new-albany-pilot-program-brings-entrepreneur-experience-students

Osterwalder, A., \& Pigneur, Y. (2010). Business model generation. Hoboken, NJ: John Wiley \& Sons, Inc.

Purdue Polytechnic Institute (2015a). Integrative, multidisciplinary, entrepreneurial capstone experiences faculty grant

Purdue Polytechnic Institute (2015b). Transformation implementation plan.

Suddeath, D. (2015, July/August). Teaching how to make dreams a reality. Southern Indiana Business Source, 16-19. Retrieved from https://www.joomag.com/magazine/business-source-july-august-2015/0073844001435851338?page=16

The National Association of Colleges and Employers (2016). Career readiness defined. Bethlehem, PA: The National Association of Colleges and Employers 1. Retrieved from: http://www.naceweb.org/uploadedfiles/pages/knowledge/ articles/career-readiness-fact-sheet.pdf

Villa, R. A., Thousand, J. S., \& Nevin, A. I. (2013). A guide to co-teaching. Thousand Oaks, CA: Corwin.

Wagner, T. (2012). Creating innovators. New York City, NY: Scribner. 